\title{
11. Dan Davin: The literary legacy of war $^{1}$
}

\author{
Janet Wilson
}

'How long will the War last'? 'For the rest of our lives'.

- Dan Davin, For the Rest of Our Lives (1947)

\section{Davin's Writing About War}

The New Zealander Daniel Marcus Davin (1913-90) had a varied, fulfilling and, by most standards, very successful war. Yet his considerable achievements during these years - three times Mentioned in Dispatches, promoted to captain in 1942, to major in 1943, and the MBE (Military Division) in 1944-are perhaps less important today than his scholarly and literary legacy, which covers writing in different genres and includes unpublished poems, diaries and letters. ${ }^{2}$ Davin's prodigious output covering his experiences and those of other New Zealanders in the 2nd New Zealand Expeditionary Force (2NZEF) whom he worked alongside in the Mediterranean and Northern African campaigns confirms that writing about war while he was in the midst of it engaged him as much as the business of fighting. For Davin, more than most, the war exerted a powerful influence over his life and work, often emerging in unexpected ways and so always a vital presence. These six years retained their tenacious hold on his memory and imagination, because the firsthand experiences of war provided unparalleled opportunities for him as a writer, offering a rich resource. His impressions and responses are depicted memorably and vividly in the stories published in The Gorse Blooms Pale (1947) and in Breathing Spaces (1975), later collected in The Salamander and the Fire: Collected war stories (1986); they also form the basis of his war novel, For the Rest of Our Lives (1947), and the background to the later novel The Sullen Bell (1956).

After the war, this engagement continued and brought him back into closer contact with New Zealand and the provincial society from which he had departed,

\footnotetext{
1 I would like to thank Doug Munro for his valuable editorial assistance, for undertaking some research in New Zealand, and for suggesting sources; also Denis Lenihan, James McNeish and Kevin Ireland for commenting on a draft of this chapter; and to Delia Davin for a careful reading of the final draft.

2 These are available in the Daniel Marcus Davin Literary Papers, Alexander Turnbull Library [hereinafter ATL], MS-Group-0319. Davin's service record with the 2NZEF from June 1940 to July 1945 is in the archive of the New Zealand Defence Force.
} 
in 1936, as a Rhodes Scholar to Oxford. Davin became the official historian of the Crete campaign. As an eyewitness of the German airborne assault on Maleme airport on 20 May 1941, he had written an account for British GHQ while in a hospital in Cairo recovering from wounds received during the attack. General Howard Kippenberger commissioned him to write the volume on Crete in the 'Official History of New Zealand in the Second World War' series. ${ }^{3}$ In 1948, he returned to New Zealand for the first time in 12 years, to undertake archival research and discussions with historians in the War History Branch of Internal Affairs, and senior figures in the armed services. The 700-page account was laboriously completed after several years of working at nights and on weekends while he held down a day job as academic publisher for Oxford University Press. Crete takes its place as a 'classic', as Kippenberger called it, among official war histories anywhere, such as W. G. McClymont's To Greece. ${ }^{4}$ It was praised by one reviewer as 'a first class piece of military scholarship' and as 'far and away the most comprehensive' of the official war histories. ${ }^{5}$ It immediately became the definitive account - one which, points out his biographer, could not be overlooked in the writing of any subsequent military history of the Crete campaign or of the Mediterranean theatre of war in general. ${ }^{6}$ The Crete volume has received justifiably high praise from other quarters: 'To write lucidly about war, without falling into the heroic simplicities that trivialize war's tragic chaos, is extremely difficult. Davin succeeds'. ${ }^{7}$ But writing the history was time-consuming, painstaking work and it exacerbated the tensions Davin experienced by working in different genres between ascertaining the truth of any matter as far as was possible and the greater freedoms that invention allowed. ${ }^{8}$ History as his primary discipline led him to have an 'excessive respect for those facts that can be established at the expense of the power to create' $;{ }^{9}$ but working with facts slowed the creative processes and he preferred 'writing with

3 Dan Davin, Crete (Wellington, 1953). For background on the series, see Michael Bassett, An Overview of the War History Branch (<http://michaelbassett.co.nz/article_war.htm>, 1997). The War History Branch files relating to the Crete volume are in Archives New Zealand (Wellington), IA1, 3388, 181/32/2, parts 1 and 2.

4 See Nancy M. Taylor, The New Zealand People at War: The home front (Wellington, 1986), vol. 1, p. ix.

5 The first quotation comes from The Economist, 23 January 1954-quoted in Keith Ovenden, A Fighting Withdrawal: The life of Dan Davin, writer, soldier, publisher (Oxford, 1996), p. 247-in a review probably written by Bill Williams. W. E. Murphy praised Crete as 'far and away the most comprehensive of the official war histories'. W. E. Murphy, 'Crete', Comment: A New Zealand quarterly review, 33 (1967), pp. 28-30. In fact, Murphy was responsible for preparing the narrative of the battle, which was sent to Dan in Oxford in 1948 (Ovenden, A Fighting Withdrawal, pp. 237-38, 246; Davin, Crete, p. viii). Other reviews of Crete include L. S. Hart, 'Disputed Island', New Zealand Listener, 6 November 1953, pp. 12-13.

6 Ovenden, A Fighting Withdrawal, p. 249.

7 Donald Harman Akenson, Half the World from Home: Perspectives on the Irish in New Zealand, 1860-1950 (Wellington, 1990), p. 90 (ch. 4: 'Dan Davin, Irish Catholic Historian').

8 Davin's comments on the writing of fiction confirm this 'troublesome...quandary': he 'preferred to set my stories within real battles, or real situations out of battle', because his training as a historian left him 'unable to name a place or even cite a map reference which was not at least hypothetically compatible with the topographical reality'. Dan Davin, 'Introduction', The Salamander and the Fire (Oxford, 1986), p. xiii.

9 Ovenden, A Fighting Withdrawal, p. 366. 
the brakes off', as he confided to the historian Angus Ross, himself the author of an official New Zealand war history. ${ }^{10}$ After Crete, he never really recovered his momentum in writing fiction.

Alongside the historical assessment of the war in Crete, and the imaginative encounter with war informing his fiction and poetry, Davin also helped get into print the works of others who were writing about the war. His role as an academic publisher at the nerve centre of publishing in Oxford for more than three decades, his historical research and reputation as an authority on the New Zealand Division's presence in the Mediterranean and North Africa, and his considerable output as a fiction writer, made him a reference point for those who needed advice and guidance. He assisted with the finalising and publishing of other histories and memoirs - for example, the draft chapters on the Greek and Crete campaigns for Angus Ross who wrote on the history of 23 Battalion (1959) and Kippenberger's war memoirs, Infantry Brigadier (1949). ${ }^{11}$

This chapter, then, will focus on Davin's writing about the war pre-eminently as fiction writer, and will locate his experiences of the war as background to his stories. Both his experiences and the writing about them illustrate the truth of the epigraph, which is also the title of Davin's war novel: the war was the formative, unforgettable experience - one that would remain with him for the rest of his life.

\section{Davin's War Experience}

At different times, Davin served in both the British and the New Zealand Armies, moving through the ranks from front-line soldier to become Divisional Intelligence Officer for General Freyberg. He first saw action in 1940 with the 2NZEF (of which the main fighting component was known as the 'Div.') as Second Lieutenant with 23 Battalion (Otago and Southland) and Commander of 13 Platoon C Company, while he spent the last year of the war working for the Control Commission for Germany in the War Office in London. During his five years of service, Davin experienced action as an infantryman in the Mediterranean campaign and then as Battalion Intelligence Officer in the German aerial bombardments of Maleme airport in Crete in 1941; he worked

\footnotetext{
10 Margot Ross and Angus Ross, 'Writing About the War', in Janet Wilson (ed.), Intimate Stranger: Reminiscences of Dan Davin (Wellington, 2000), p. 64. Davin's output peaked in the years between 1945 and 1953. He published three novels: Cliffs of Fall (London, 1945); For the Rest of Our Lives (London, 1947); and Roads from Home (London, 1949); and a collection of short stories, The Gorse Blooms Pale (London, 1947). He completed John Mulgan's An Introduction to English Literature (London, 1947) and edited two volumes for the Oxford University Press World's Classics Series - New Zealand Short Stories and Katherine Mansfield: Selected stories (both in 1953) - as well as writing numerous reviews and articles.

11 Howard Kippenberger, Infantry Brigadier (London, 1949); Angus Ross, 23 Battalion (Wellington, 1959); Ovenden, A Fighting Withdrawal, pp. 227, 238; Ross and Ross, 'Writing About the War', p. 63.
} 
for the intelligence staff of the Eighth Army GHQ in Cairo from August 1941 to September 1942; he took part in the Northern African desert campaign against Rommel in 1942, in the employment of the British Army J Staff Information Service; and after El Alamein he served with General Freyberg in the Italian campaign for six months in 1944 as Chief Intelligence Officer (in army terminology, GSO 3 [1]) for the Div., at the time the New Zealand Corps (the special unit that existed from 3 February to 26 March 1944) was formed to bomb Monte Cassino. ${ }^{12}$ Serving in these different posts and discharging their duties meant that Davin participated in front-line action, intelligence gathering and decision-making processes, and became familiar with the operational and tactical aspects of war from the top down as well as the bottom up.

His own trajectory through the ranks, therefore, is reflected in the range of military types he introduces into his fiction, and their different attitudes, perspectives and values according to rank and experience. The relationship he had with General Freyberg when working in intelligence, for example, emerges in the portrait of the Staff Intelligence Officer in 'North of the Sangro' who is obliged to dampen his general's bursts of enthusiasm and obsession with the superior might of the Russian forces - his 'visions of dislodging the Germans from the more hideous bits of high ground like the Majella Massif itself and to fantasies of moving at the same pace as the Russian[s] were now moving in one sector after another of their enormous front' - by 'present[ing] him with an accurate but tough assessment of the situation from the enemy point of view'.$^{13} \mathrm{He}$ is equally preoccupied with the other extreme of the military hierarchy: with the batman or driver-minor figures usually overlooked in narratives of conquest and defeat, but whom Davin idealised as epitomising the commonsensical, egalitarian Kiwi soldier, distinguished by a flair for the vernacular. His batmen are dependable, likeable characters who are also fluent storytellers, and their colourful nicknames epitomise the intimacy of the officer/ soldier relationship (in contrast with the menace suggested by nicknames of officers such as Sabretooth in 'Psychological Warfare at Cassino'): Chaffcutter in 'Finders and Losers', so-called because he is clumsy, treats the narrator gently when he contracts yellow jaundice,; Jumbo Jordan in 'North of the Sangro' has an ear for nuance and speaks the Kiwi soldier's creative slang, ${ }^{15}$ while Smithy in 'Psychological Warfare at Cassino' is a 'rough diamond' who could 'spin endless yarns of heroic behaviour' ${ }^{16}$ In one of Davin's best-loved stories, 'The General and the Nightingale', the military extremes of the servant-master hierarchy

12 See Davin, The Salamander and the Fire, p. 134.

13 Davin, The Salamander and the Fire, p. 101.

14 Ibid., pp. 75-6.

15 Ibid., p. 109.

16 Ibid., p. 125. 
emerge in the voices of the three batmen who slyly caricature the idiom, manner and authority of their masters, reduplicating the structure of command as they settle down to gossip among themselves:

'Billy's boiling, GI,' he [Plugger Holmes] announced. 'Make the tea, will you? And, AQ, I like my fritters well done on both sides. You'd better turn them over, hadn't you?' It was the General's voice and manner, exactly mimicked but with asperity slightly exaggerated. And there was something of the original's authority. ${ }^{17}$

These years marked formative events in Davin's private life - mostly happy but some unexpected, despite or because of the inevitable separations that war brings about. Davin had married his New Zealand fiancée, Winifred ('Winnie') Gonley, after completing his three-year Rhodes Scholarship tenure in Oxford in May 1939, just before war was declared. Two of their three children were born while he was on active service: Anna Deirdre, in September 1940, Delia (called Helen until the age of seven, then Delia) in June 1944, while the third, Katharine Brigid (known as Brigid), was born just after war ended, in November 1945. ${ }^{18}$ There was another child, Patricia Katarina (called 'Patty'), born out of wedlock in December 1943 to Elisabeth Berndt, an expatriate German with whom Davin had a love affair in Cairo in 1942-43. He and Winnie- once her anger had subsided - welcomed Elisabeth and Patty into the family home in Southmoor Road in Oxford. On the other hand, there were losses: his mother died suddenly of a coronary thrombosis at a mental hospital in 1944-a death that Davin heard about only some time later via a letter from his older brother, Tom. ${ }^{19}$

There was also the shock of witnessing sudden death and facing the moral implications of apparently controlling the fates of others under one's commandboth unavoidable in war. Mortality and the transience of life are major war stories. Early on, he was faced with the deaths of three men and the capture of another three with whom he served in the Greek campaign of April 1941soldiers whom he commanded as leader of 13 Platoon and whose lives he felt keenly responsible for. ${ }^{20}$ Davin's platoon was ordered to hold one end of the line on a ridge running parallel with the main Olympus Range and then when it was clear that the German advance could not be halted, they pulled out; the men retreated with the remnants of the Central Macedonian Army from Salonika over Mount Olympus, the eastern seaboard of Greece, to Athens, in a 'fighting withdrawal'. The difficulties of this operation in which his men

17 Ibid., p. 173.

18 Winnie Davin's wartime experiences are recounted in 'A Soldier's Wife', in Lauris Edmond (ed.), Women in Wartime: New Zealand women tell their story (Wellington, 1986), pp. 65-75; and in 'Memories of Wartime Experiences', ATL, MS-Papers-3839.

19 The coronial inquest file relating to Mary Davin is held at Archives New Zealand (Wellington), J46, $1944 / 1116$.

20 Ovenden, A Fighting Withdrawal, p. 140. 
were dangerously exposed, magnified by the wet, muddy conditions caused by melting snow after a blizzard on Mount Olympus, are recounted in 'Below the Heavens', the opening story in The Salamander and the Fire. Three men from Platoon 13, emerging from their slit trenches, manage to attack a group of advancing Germans in their first close-up engagement: the story turns on the reactions of one of them to a mortally wounded Jerry who begs for a mercy killing; one of the trio did finally put the 'poor bastard' out of his misery. ${ }^{21}$

The upheavals of war threw up new opportunities for meeting people, and during these crucial years the gregarious Davin forged many new friendships - some of them brief, as with Lieutenant W. H. (Wattie) McKay, a journalist in civilian life who died of wounds in August 1941. ${ }^{22}$ Others were lifelong — most importantly, with the brilliant linguist from Auckland Desmond (Paddy) Costello, who, like Davin, was Irish-Catholic by descent and a classicist (he studied Greek at Trinity College, Cambridge, and had been a Lecturer in Classics at the University of Exeter). So intense was this friendship that they have been described as 'blood brothers' ${ }^{23}$ Costello's reputation for the feat of guiding the remnants of 21 Battalion out of Greece across the sea to Crete, due to his ability to speak Greek, had preceded him by the time they met at the National Hotel in Cairo where Davin was training for Intelligence in Eighth Army GHQ. They became fast friends, and this was to be cemented through their positions as General Freyberg's Intelligence Officers. ${ }^{24}$ War also threw Davin into new relationships with his contemporaries - notably, Geoffrey Cox who had also studied at Otago University and at Oxford, and with whom he briefly shared a flat in Cairo. It was Cox who introduced Davin to Costello. ${ }^{25}$ All three men-Cox, Costello and Davin - were at different times Chief Intelligence Officers for the Div.: Cox in 1942, Costello in 1943, then Davin in 1944, before he was transferred to the Ministry of War in London. This was largely due to General Freyberg being attracted to intellectual and artistic types, clever young men whose opinions he listened to. ${ }^{26}$ The way that Freyberg snatched his officers from the Eighth Army GHQ training school as soon as they were ready in 1942-43 is pointed out in 'Psychological Warfare at Cassino' ${ }^{27}$ The relationship was one of mutual suspicion mixed with admiration and trust as Freyberg, despite his powerful influence, came to depend on his Intelligence Officers for their company, as well

\footnotetext{
21 Davin, The Salamander and the Fire, pp. 1-11.

22 Ovenden, A Fighting Withdrawal, p. 135.

23 James McNeish, The Sixth Man: The extraordinary life of Paddy Costello (Auckland, 2007 ), p. 381.

24 Ibid., pp. 106-7; Ovenden, A Fighting Withdrawal, pp. 153-4.

25 James McNeish, Dance of the Peacocks: New Zealanders in exile in the time of Hitler and Mao Tse-tung (Auckland, 2003), pp. 199-200. See also McNeish, The Sixth Man, pp. 111-12; Ovenden, Fighting Withdrawal, p. 177.

26 Ovenden, A Fighting Withdrawal, p. 177.

27 Davin, The Salamander and the Fire, p. 123.
} 
as advice. Davin recalls him affectionately in three stories all based on factnotably, 'North of the Sangro', in which, brooding over the good men he has lost so far, the General says to his Intelligence Officer:

I care about our men. And so many of them whatever I do or say will be dead...Another few years, just to make it worse and the historians who have never heard a bullet whisper who weren't even out of their cradles in 1939 will be explaining to the next generation how it was all my fault. ${ }^{28}$

In 'Psychological Warfare at Casino', the narrator (that is, Davin) dwells on the General's increasing attachment to Des Cassidy (that is, Costello) during the period when he was on leave in England: 'the General had become devoted to him and refused at first to let him take his period of allotted leave. Des was supposed to go on leave as soon as I got back but the General had found one pretext after another for hanging onto him. ${ }^{29}$

Other wartime friendships included the history don from Merton College, E. T. (Bill) Williams (later Master of Rhodes House), head of Montgomery's intelligence in 1944, whom Davin met at GHQ in Cairo and remained a loyal friend and ally during the war, and then during Davin's years as academic editor for the Clarendon Press. ${ }^{30}$ John Willett, a modern languages graduate from Oxford, was another good friend, and so was Reggie Smith, who had been working for the British Council in Bucharest, and married the novelist Olivia Manning. Davin met them briefly at the house of Walter and Amy Smart in Cairo- Smart was Oriental Counsellor at the British Embassy - where he also met Elisabeth Berndt, who was the Smarts' nanny. ${ }^{31}$ There was also Noel ('Wig') Gardiner, whom Davin met in 1943 at the staff training college in Sarafand, Palestine, a machine gunner who won a Distinguished Service Order (DSO) on Miteiriya Ridge during the battle of El Alamein, and who, according to Ovenden, 'opened Dan's ear to the vernacular in the New Zealand language, and taught him how to hear it, copy it and use it in his fiction'. ${ }^{32}$

The variety of friendships, love affairs and acquaintances was one consequence of the haphazardness of war, which threw people together in unexpected ways, as occurred in Cairo in the early 1940s - then a melting pot of many nationalities and creeds, described as 'the cosmopolitan capital of the old world, everything that Berlin and Paris had been between the wars'. ${ }^{33}$ The apparent randomness

\footnotetext{
Ibid., p. 112.

Ibid., p. 119; McNeish, The Sixth Man, pp. 128-33.

30 Williams had a New Zealand connection, studying there in the late 1930s on a Harmsworth Scholarship.

Tim Beaglehole, A Life of J. C. Beaglehole: New Zealand scholar (Wellington, 2006), pp. 255-6.

31 Ovenden, A Fighting Withdrawal, p. 157.

32 Ibid., p. 166.

33 Ibid., pp. 152-3.
} 
of movement was also magnified by military command's habit of moving men about in the Div. as the war wore on, bringing in younger men as the senior military officers became fewer either 'because of casualties or relegation to duties in the rear'.$^{34}$ Davin's charisma and innate egalitarianism flourished under such circumstances - moreover, he soon found that he could put to good use his intellectual talents and resources, not unlike other scholars with classical backgrounds and a gift for languages, such as Sir Ronald Syme (who was present at Dan's viva in Oxford) and Enoch Powell (whom Davin met on an officers' training course in England and again at GHQ in Cairo). ${ }^{35}$ War, therefore, was a theatre of action in which Davin applied his academic skills to the demands of intelligence, defined himself as a man among men, and, on more than one occasion, romantically in relation to women.

Dan Davin epitomised the wartime scholar-soldier in that he combined the gifts of scholarship - to assess, analyse and to write succinctly - with courage and an ability to work both independently and with others. He was a verbal tactician, no doubt taking his cues from his extensive reading in Caesar and the classics; he famously spent his spare time reading the Aeneid in the original during the battle of El Alamein. ${ }^{36}$ He excelled in writing dispatches, at making inferences from information and reports about the enemy, and at providing concise intelligence summaries. There seems little doubt, for example, that his report on the German parachute assault in Crete, written at the request of Colonel Quilliam in Army Intelligence, led to the decision to recruit Davin from the infantry into the intelligence staff at GHQ. ${ }^{37}$ The excellence of his reports for J Squadron, the British Army group of mobile units that reported directly on the conduct of operations to Army HQ from the forward positions, led Geoffrey Cox, news reporter, journalist and later founder of News at Ten, to comment:

Dan's capacity for assessing and marshalling information quickly, an invaluable by-product of his years of rigorous scholastic training, and his willingness to draw deductions and stand by them gave his reports in J Squadron an outstanding quality. The Merton Don, Bill Williams, then as Colonel Williams, the head of intelligence at Montgomery's HQ, told me many years later that he quickly realised he could place firm reliance on any report that came in with the signature 'DM Davin, Capt. ${ }^{38}$

Costello, Cox and Davin were a formidable team in intelligence. According to McNeish, the 'trio of scholars' provided the general with 'a flow of intelligence summaries and reports that would be the envy of rival Allied commanders for

34 Davin, The Salamander and the Fire, p. ix.

35 Ovenden, A Fighting Withdrawal, pp. 123, 128; McNeish, Dance of the Peacocks, pp. 196-7.

36 McNeish, Dance of the Peacocks, pp. 218-19.

37 Ovenden, A Fighting Withdrawal, pp. 150-1; McNeish, Dance of the Peacocks, pp. 192, 196.

38 Sir Geoffrey Cox, 'Dan Davin: Soldier', in Wilson, Intimate Stranger, p. 54. 
the duration of the war'.$^{39}$ The respect that all three won from the New Zealand military command led to other careers: Cox, after working for Freyberg, served as First Secretary of the New Zealand legation in Washington, DC, in 1942-43; Costello became a diplomat and First Secretary of the newly established New Zealand Embassy in Moscow in 1944; Kippenberger, even before his return to New Zealand in 1946 as Editor-in-Chief of the New Zealand war histories, had asked Davin to write the volume on the Crete campaign, while Freyberg, when about to take up the position of Governor-General of New Zealand, gave Davin access to his personal archives. ${ }^{40}$

For Davin, then, in both the professional and the personal realms of his life, war was more than a testing ground: it was a crucial axis round which his life perspectives, personal ambitions and values came to be shaped, particularly in relation to New Zealand, creating pride in the society he had come from; writing the short stories and the novel kept alive his name in connection with the war, while Crete gave him status among military historians, and authority among other New Zealand senior officers of staff. Most significantly, the war was the crucible for his writing of fiction - the activity for which at that time of his life he cared most passionately. ${ }^{41}$ These years retained a tenacious hold on his memory and imagination, and their influence on Davin's later life exceeded their tangible achievements, relationships and experiences: the firsthand encounter with fighting, the acquaintance with suffering and death, and the mechanics and operations of war provided unparalleled material for his literary endeavours. Geoffrey Cox summarises the way that these intense experiences developed Davin's writing abilities:

The war years were of deep importance in Dan's development as a novelist. They provided him with topics and scenes and characters in abundance for his later writings. But also they were years in which he lived deeply and fully, and in which he undoubtedly gained an added confidence in himself and his talent. ${ }^{42}$

\section{War, Writing and New Zealand}

When war was declared on 3 September 1939, Davin had just completed Greats at Balliol College, Oxford (gaining a first). He was in Paris on his honeymoon with Winnie (née Gonley), also of Irish-Catholic descent and from Otautau,

\footnotetext{
39 McNeish, The Sixth Man, p. 112.

40 Ovenden, A Fighting Withdrawal, p. 236.

41 Davin had already written one novel, Cliffs of Fall (1945), and lost the manuscript of a second novel in the retreat over Salonika.

42 Cox, 'Dan Davin', p. 56.
} 
near Invercargill. They had met while students at Otago University in 1931. Davin's biographer paints a vivid picture of their departure from Paris following Germany's invasion of Poland on 1 September (coincidentally Davin's twentysixth birthday): the tears of the concierge in the flat they were staying at in the rue Delambre; their farewell to Geoffrey Cox, then a war correspondent, at his office in the France Soir building:

When they had last seen him, the office was busy, Geoffrey constantly on the phone to Berlin, London or Rome. [Now] he was alone, his feet on a desk, the telephones silent. There was nothing more to say. Diplomacy was finished. [His] suitcase was in the corner of the room packed and ready. ${ }^{43}$

After returning to England, Davin enlisted, vowing to ensure his mortality by fathering a child and completing a novel before he was killed. Unaware of the options available for scholars such as himself with knowledge of languages in areas such as supply, economic warfare or intelligence- he went before the Military and Government Recruitment Board at Oxford, was recruited for the British Infantry and assigned to the Royal Warwickshire Regiment in January 1940. But after training in Aldershot for some months, he requested a transfer to the 2NZEF, and in July took up his commission as a second lieutenant with 23 Battalion (Canterbury and Otago), at Mytchett, Surrey. ${ }^{44} \mathrm{He}$ thus found himself back in the company of men from Southland and the West Coast where he had grown up - people whom the Catholic, university-educated Davin had not encountered since he left Invercargill in 1930 for his final year at Sacred Heart College in Auckland, and then for the University of Otago on a National Scholarship. ${ }^{45}$ Being in the midst of familiar accents and characters made him rediscover his roots after five years away, with a renewed sense of identitythat of being a New Zealander after all. He saw that he was working within a microcosm of the society he had left, writing: 'In parts this battalion is a travelling Invercargill, a peregrinating small town impregnable...in the complacencies of its provincialism. ${ }^{\prime 6}$ The Div. then came to act as a bridge, linking Davin's life back to New Zealand origins. Geoffrey Cox describes his impressions of the men of 13 Platoon C Company in the summer of 1940, with Dan as their commander, in Mytchett:

Dan came past, marching at the head of his platoon. Under the high peaked hats which we still wore at that stage of the war, before they were abandoned for forage caps and berets, Dan's face was dour and set. The

\footnotetext{
43 Ovenden, A Fighting Withdrawal, p. 125.

44 Ibid., p. 127.

45 Father John Pound, 'The Marist Brothers, Invercargill', in Wilson, Intimate Stranger, p. 26; Ovenden, A Fighting Withdrawal, pp. 42-3.

46 Quoted in Ovenden, A Fighting Withdrawal, p. 137.
} 
faces of the men behind him, mostly West Coast miners, farm workers and road makers from Southland, were typical of those early 2NZEF... volunteers, alert, hard-bitten, sardonic, the faces of men hardened and shaped by the rigours of the Great Slump, of the 30s. They were men who matched the hour as Dan too showed that he could do so in the testing years that lay ahead. ${ }^{47}$

Working within the ranks of the New Zealand Division awakened a complex sense of national pride that had been dormant at the time he departed from New Zealand at the age of twenty-three, frustrated by its provincialism and keen to explore wider horizons. Davin's understanding of national identity was male oriented, based on comradeship and a discovery of the ordinary, as McNeish puts it, in speaking of both Costello and Davin - of 'something outside themselves that was not intellectual'. ${ }^{48}$ It was inevitably informed by values that war tested, such as the egalitarian belief that courage and proven ability in warfare should rank higher than training, hierarchy or privilege. As Davin says in the introduction to The Salamander and the Fire: after the initial sorting into officers, men and NCOs which was originally based up on the degree of education, obvious qualities of leadership and aptitude, everything depended, if the links of confidence were to be preserved, on merit as proved in battle. ${ }^{49}$ The imputation of physical cowardice to soldiers who held positions of leadership, and the exploration of its effects on the subject, is the focus of at least two stories. Davin's working-class affinities come out in the way he associates fear and its dire consequences with men from privileged backgrounds, or of officer class: in 'Coming and Going', Major Reading, whom the narrator encounters in the mess of the base camp at Maadi, comes from Christchurch, took an interest in territorials and is not the sort of person the narrator would know outside the Army: 'Chaps like him had got off to a flying start when the war broke out', ${ }^{50}$ the narrator notes; but on the occasion of a counterattack, Reading had '[c]leared out, Ratted, Buggered off. Said he had to report back to battalion. ${ }^{51}$ Reading finally shoots himself rather than face the disgrace of repatriation. Equally chilling in its exploration of the psychology of the coward is 'East is West': the narrator, a sergeant, is picked up by Captain Curtis in his truck after his tank is blown up and his friend George killed; but the truck then becomes separated from the convoy in the desert and runs into a minefield. Curtis's miscalculations and fears, which he covers up by pulling rank, set up tensions with the others,

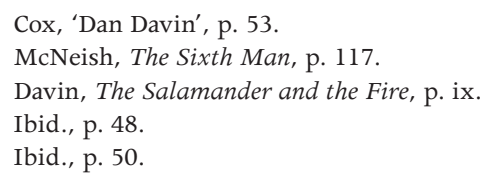


and when his legs are blown off by a mine the sergeant waits for him to die instead of shooting him as he begs him to, saying later to himself: 'I'd have known it was all right [to shoot him] if it'd been a pal like George. ${ }^{52}$

Davin's nationalist leanings hinged on his confidence in the New Zealanders as a fighting force, because in other ways he became restless in their company. Costello had invented the Div.'s slogan-'Hooray fuck' - and this summarised their anti-authoritarian bravado. Davin's diary confirms this impression: 'I just could not believe the Germans would get past our line at Alamein, past Paddy, past Freyberg, and those high New Zealand voices, full of confidence and courage, I had heard passing through the Cairo night.. ${ }^{153}$ Serving with the Div. throughout most of the war, writing about it in fiction, reinforced by the research for Crete, anchored Davin in his New Zealand identity in ways that would not otherwise have been possible. It remained with him for the rest of his life although coupled with the growing recognition with time that by remaining on the other side of the world, he was also cutting himself off. As he wrote to the New Zealand novelist Frank Sargeson almost a decade after the end of the war: 'I feel no wish to write about anyone but NZers - indeed don't feel or don't feel in the same way about anything else - and all the time the old navel cord is getting more shriveled. ${ }^{54}$

All but two of the 19 stories in The Salamander and the Fire are about New Zealanders at war. Male comradeship - its expectations and betrayals - is a leitmotif; women are absent but influential, invoked indirectly through memory and dream, and they are addressed in their absence through letter writing, as in the comical but sad story in 'Finders and Losers' of the narrator's friend Herbie, from Southland Boys' High School and Otago University days. Herbie, now a fellow soldier, had married, above his class, the daughter of a Canterbury sheep farmer: he persuades the narrator to compose letters to convince his wife that he is staying out of danger by taking on a safe camp job, although in the end he dies before he receives the 'Dear John' letter he had been anticipating. Davin's narratives about the adjudication of friendships and carefully negotiated relationships between men who are not equals in rank can be compared with Frank Sargeson's stories and anecdotes about male friendship, permeated by hidden tensions and jealousies, marked by their homosexually loaded subtexts, which were published in the 1930s, stemming from that other great social crisis, the Depression. Davin's concept of mateship relies on shared action and common

\footnotetext{
52 Davin, 'East is West', Breathing Spaces (London, 1975), p. 119.

53 McNeish, The Sixth Man, pp. 114-15.

54 Quoted in Wilson, Intimate Stranger, p. 101. A broader discussion of fictional writing about World War II by New Zealanders, including Davin, is provided by Jock Phillips, A Man's Country?: The image of the Pakeha male: a history (Auckland, 1987), pp. 198-215.
} 
goals and, as with Sargeson's values, it thrives because it is underpinned by a code of loyalty. The protagonist in For the Rest of Our Lives, Frank Fahy, sums it up:

For the first time in his life, Frank, impervious to the self-conscious esprit de corps of school and university, found himself deep in a group loyalty which he unequivocally shared. Here were men associated with a common purpose, who had built up in their two years campaigning a tradition of boldness, efficiency and resource. ${ }^{55}$

In Davin's stories, male bonding occurs through verbal, intellectual encounters: playing chess, trading ideas through wit and repartee, and conversations involving gossip, rumour and stories. 'Bourbons', for example, focuses on an off-duty English major and two captains in the western desert luxuriating over bourbon and cheroots, enjoying their conversation about 'home' and their guaranteed postwar futures, who wander over to the wireless truck - the men's resort of an evening — where they 'felt the loss of home', to listen to the news. ${ }^{56}$ This emphasis reflects the convivial atmosphere that Dan thrived on, in which his conversational skills and aptitude to listen to others as well came into their own. During 1942-43, he and Paddy would hold court each night in the ' $\mathrm{I}$ ' (Intelligence) truck known as the 'Café' or the 'Bistro', in contrast with the regular staff officers' Armoured Carrying Vehicle, the 'Tin Chapel' (so-called because the officers carried their training manuals like prayer books); ${ }^{57}$ in this 'home of amateur intellectuals', intelligence was gathered, troop movements on different fronts were discussed, there were singing, joking and yarning. The telling of stories is an innate part of such entertainment and such gatherings were a fecund source of Davin's tales, many of which are anecdotal, displaying oral storytelling mannerisms, passed down from one narrator to another.

Davin wrote many of his stories - both about the war and about his Southland childhood - in periods of inaction during the war when he had time to write, reflect and concentrate on ways of representing events. The stories in The Salamander and the Fire are grouped so as to form an image of his own trajectory in moving from Greece to Crete, Cairo, North Africa, Palestine and Italy. ${ }^{58}$ This does not reflect the order in which they were written, but gives a thematic coherence to the collection, as the opening stories that dwell on initiation into war contrast with the sombre, meditative tone of the final stories, in which Davin's narrators brood on the fate of his generation in what becomes a virtual 'anthem for doomed youth'. There is a world of difference from the more subjective, impressionistic mood of early stories such as 'Under the Bridge', in

55 Davin, For the Rest of Our Lives, p. 55.

56 Davin, The Salamander and the Fire, pp. 54-8.

57 Ibid., p. 199.

58 Ovenden, A Fighting Withdrawal, p. 383. 
which the narrator forces himself to look down at the mass of bodies of those who had been sheltering under a bridge that has been bombed, and experiences an existential moment of ontological denial:

I listened again. Not a groan or sigh...I hesitated. In sudden horror, I knew there was something else dragging me to the edge. Appetite for frightfulness as well as revulsion. Death squatted within the hollow like a presence, its emanation came up grisly, dragging at me. I felt the hair on the back of my head stiffen, I took two steps forward. My eyes saw but my brain would not see, I turned and ran. ${ }^{59}$

The subjective response to war experiences - significantly correlated to Davin's own - is at the centre of these fictions; but Davin's technique is often to develop its narrative potential. 'Danger's Flower' ${ }^{\prime 0}$ takes place after the German airborne offensive at Maleme airport in Crete in 1941 where Davin was wounded. It probes the consciousness of a wounded man who, along with others, has been shifted to a cathedral because the hospital is full. During the night a girl comes round and offers each of the wounded a flower, giving Alan a carnation: 'He blushed and tears came into his eyes. There was a lump at his throat. He took the flower in his left hand and looked at it... They used to grow in the front garden at home when he was a boy. They were the first flowers he remembered. ${ }^{\prime 61}$ These details are recorded in Davin's diary for 12 September $1940 .{ }^{62}$ But onto this setting he attaches an incident of greater consequence that is either invented or based on an anecdote: Alan moves out of the cathedral with the other walking wounded in order to be evacuated from Suda Bay on a warship; with him is a young man who cannot speak English. The boy is hit by an anti-personnel bomb as they walk together; Alan, although exhausted from his own wounds, covers up the boy's wound and helps him to safety.

In contrast, the final story, 'Not Substantial Things', is evaluative and reflective, and the narrator speaks for his generation, summarising the war's meaning for the survivors, no doubt drawing on personal impressions: they had given war the best of their lives, they had burnt up their youth in its service. ${ }^{63}$ War had

59 Davin, The Salamander and the Fire, p. 15.

60 An allusion to Shakespeare, Henry IV, part 1 (1597): 'out of this nettle, Danger we pluck this flower, safety.'

61 Davin, The Salamander and the Fire, p. 19.

62 Ovenden, A Fighting Withdrawal, p. 149.

63 Ovenden (ibid., pp. 355-6) quotes from a letter from Anthony Stones, the sculptor, of how Davin in 1978 at a gathering organised by Wig Gardiner at the Auckland Returned Servicemen's Association spoke extempore: 'It was just as in his stories, he gave their memories and sentiments a form of which they were incapable. He spoke for the men there and the men who weren't there. It was a privileged thing to have seen and heard.' 
taken the flower of their manhood, yet it had also yielded riches in the forms of new friendships, company, and ways of dying as well as of living; nothing would be the same again.

We'd never give anything again what we'd given to the Div. We'd never bring the same energy to anything that we'd brought to things like the break-through at Minqar Quaim or the assault on Cassino. And we'd never be able to make friends again the same way or drink and laugh and die the same way. We'd used up what we had and we'd spend the rest of our lives looking over our shoulders. ${ }^{64}$

This seminal statement not only gives the phrase that would become the title of his war novel, it also hints at Davin's philosophy of life, articulated in the short stories and novels, as well as in non-fiction such as the memoirs in Closing Times (1975) - a volume that shows his affection for and sympathy with the thinking of Samuel Johnson: life is inextricable from death, we are ruled by transience, and exist in an indifferent, godless universe from which we are estranged. ${ }^{65}$

Davin's war novel, For the Rest of Our Lives, written in the last stages of the war when he was living and working in London, moves one step further away from the realm of action to consider the qualities of the Div. as a fighting unit. It also hints at the relationship between the men's bravery and military effectiveness and the land that had nourished them. This patriotic accolade, which embraces both the discipline imposed by the general and the inner calibrations imposed by the threat of death, suggests how the war had brought Davin back emotionally into the centre of the world, which he thought he had left:

So that in that summer of 1942 no army in the world had a division so free from incompetence, so close to perfect, with so high a percentage of men in their right places from general to private.

Yet there was more than the general and death to thank for this. There was the hard, self-reliant, democratic subsoil of life from which the men had grown, and the pride in body and brain it had given them. ${ }^{66}$

\section{Conclusion: The final years}

In retirement from Oxford University Press (1978-90), Davin found more time to pursue the legacy of the war years; but, regretfully, lengthy projects he had planned for his years of greater leisure - such as writing another novel or a

64 Davin, The Salamander and the Fire, p. 207.

65 Lawrence Jones, Barbed Wire and Mirrors: Essays on New Zealand prose (Dunedin, 1987 ), p. 86.

66 Davin, For the Rest of Our Lives, p. 320. 
memoir of his friend Paddy Costello as part of a series to be called 'Scholars and Soldiers' - were started but not completed.$^{67}$ Suffering from ill health, writer's block and depression, Davin turned to less taxing forms: the short story, the brief memoir and the literary essay. Writing on the war and reflecting on those years loomed large among these activities. He typed up his war diaries for the period 1940-44, and, as Chairman from 1980 to 1983 of the Salamander Oasis Trust - a charity that aimed to publish the work of servicemen from the North African campaigns of 1940-43- he revived his earlier interest in publishing about the war; he assisted in the finalising of many manuscripts and saw into print a second anthology, From Oasis into Italy (1983).$^{68}$ Time and attention were devoted to the editing of his friend Wig Gardiner's book about his war years, Freyberg's Circus (1981); and, for Oxford University Press, he compiled Night Attack: Short stories from the Second World War (1982), which included stories by Kingsley Amis, Elizabeth Bowen, V. S. Pritchett, Graham Greene and Julian McLaren Ross, as well as two of his own. Most importantly, he wrote a further six stories about the war-mainly on the Italian campaign - deepening them with reflections about his Southland childhood as in 'When Mum Died', or by using reflections of war to introduce an episode from his early years as in 'Black Diamond'. These were first published in New Zealand journals and collectionsthe New Zealand Listener and Islands - and are among the 19 stories collected in The Salamander and the Fire (1986). ${ }^{69}$

Davin's social habits had become entrenched due to the evenings spent with Costello and others in the 'I Café' and in Soho pubs subsequently. With Winnie, he maintained a social circle in various local pubs near where they lived in Jericho, Oxford; old and new friends, and members of the press would drop in, as would local and visiting academics including New Zealanders who were either visiting or domiciled in England. In this way, they kept up those ties with New Zealand that Dan also sustained through literary and scholarly avenues: through correspondence with authors such as Sargeson, through reviewing recent New Zealand writing for the Times Literary Supplement, writing stories about his childhood, writing memoirs and obituaries of academic colleagues such as Norman Davis and Jack Bennett (both Professors of Medieval English at Oxford), as well as critical essays. There were also return visits with Winnie in which they reconnected with family and friends: in September 1978, the year of his retirement, and again in December 1984 to receive an honorary Doctorate of Literature from the University of Otago. In 1987, on New Year's Day, Dan Davin was appointed CBE in the New Zealand lists.

67 Ovenden (A Fighting Withdrawal, pp. 364-6) suggests that Davin's frustration at the inability to complete this project-partly due to lack of access to Costello's papers, and his desire to clear Paddy of charges of espionage - overshadowed his later years.

68 He included his own works: the diary extract 'Eavesdropping at Alamein' and a poem, 'Lybian Epitaph'.

69 With the exception of 'East is West' and 'Black Diamond'. The latter is published in Janet Wilson (ed.), The Gorse Blooms Pale: Dan Davin's Southland stories (Dunedin, 2007), pp. 255-65. 
Davin ended his life already a figure of legend. Long before his death on 28 September 1990, he was known in New Zealand literary circles for his contribution to the short story tradition, perhaps misleadingly as one of the 'sons of Sargeson', and to a lesser extent for his novels. His reputation as one of New Zealand's best and most prolific writers about World War II has until recently been overshadowed by these achievements in fiction, despite the range of his war publications: fiction, official history, radio broadcast (for example, with Leonard Cottrell about the fall of Crete in July 1953), and literary criticism (for example, reviewing works such as John Mulgan's posthumous account, Report on Experience).$^{70}$ Since his death this has been partly overturned with the publication of Keith Ovenden's indispensable biography, A Fighting Withdrawal: The life of Dan Davin, and with a revival of interest in the war years generated partly by James McNeish's two studies of a number of brilliant figures in Davin's generation, several of whom lived out their lives in Europe. ${ }^{71}$ Davin's war writings are unique amongst historical and political evaluations because of their generic diversity, and the way they reveal a growing national sentiment and identity and represent the collective presence of members of the Div. The future publication of his war dairies and correspondence will go some way to complete the picture of World War II that these recent biographies and studies have reconstructed, based as they are on Davin's Crete, his imaginative fiction, his poetry and his non-fictional and autobiographical writings.

70 Landfall: A New Zealand quarterly, 2:1 (1948), pp. 50-5.

71 Ovenden, A Fighting Withdrawal; McNeish, The Dance of the Peacocks; McNeish, The Sixth Man. 